\title{
Trophic plasticity of the methanotrophic mussel Bathymodiolus childressi in the Gulf of Mexico
}

\author{
P. M. Riekenberg ${ }^{1}$, R. S. Carney ${ }^{2, *}$, B. Fry ${ }^{3}$ \\ ${ }^{1}$ Centre for Coastal Biogeochemistry Research, Southern Cross University, S Block 3.30, Military Road, Lismore, NSW 2480, \\ Australia \\ ${ }^{2}$ Department of Oceanography and Coastal Sciences, Louisiana State University, Baton Rouge, LA 70803, USA \\ ${ }^{3}$ Australian Rivers Institute, Griffith University, 170 Kessels Road QLD 4111, Australia
}

\begin{abstract}
Bathymodiolus childressi is a foundation species at methane seeps on the uppercontinental slope of the Gulf of Mexico. Other species of the genus are known to gain the advantage of variable food availability through trophic plasticity, by hosting dual microbial symbionts while retaining their own particle feeding ability. B. childressi, however, hosts only a single methanotrophic symbiont, and the possibility of trophic plasticity has not been fully examined in this species. Feeding strategies of archival specimens from 2 geochemically contrasting seeps from the Gulf of Mexico (Bush Hill and Brine Pool NR-1) were characterized using 4-source mixing analysis of $\delta^{13} \mathrm{C}, \delta^{15} \mathrm{~N}$ and $\delta^{34} \mathrm{~S}$ values. Bush Hill mussels used a single thermogenic methane pool and derived $\mathrm{N}$ and $\mathrm{S}$ from different sources. Brine Pool mussels used 2 separate methane pools; the primary one being biogenic and the secondary possibly a mix of biogenic and thermogenic. Utilization of particulate material was less common at Brine Pool than at Bush Hill. Bush Hill appears to offer lower levels of methane-based resources with particulate material having a greater, and sometimes dominant role in nutrition. Spatial patterns within the seeps were found but were not reflective of simple gradients. Some temporal changes occurred at both yearly scales and between samples, which were collected $17 \mathrm{yr}$ apart. The 4 -source mixing model used extrapolations of mussel isotope values and limited environment characterization to infer likely trophic sources. The actual sources, however, remain unidentified. Future research across a wider range of seeps as well as experimental studies should be used to test the validity of the model.
\end{abstract}

KEY WORDS: Trophic mixing analysis · Cold seeps $\cdot$ Chemosynthetic communities $\cdot$ Methane seeps · Mixing model

\section{INTRODUCTION}

The mytilid genus Bathymodiolus colonizes and often maintains large populations in deep-sea habitats where geothermal venting or cold seepage provide reduced sulfur, methane or hydrogen singly or in combination at the seafloor (Olu-LeRoy et al. 2007, Cordes et al. 2009, Miyazaki et al. 2010). Trophic plasticity occurs in some species of the genus, with many possessing a dual chemosynthetic symbiosis that allows for population persistence across a range of methane or sulfide concentrations (Distel et al.

${ }^{*}$ Corresponding author: rcarne1@lsu.edu
1995, Trask \& Van Dover 1999, Duperron et al. 2007, 2013, Fontanez \& Cavanaugh 2013). Particle ingestion and assimilation have also been suggested as a source of nutrition based on dissections, variable stable isotope values and aquarium studies (Le Pennec \& Prieur 1984, Le Pennec 1988, Page et al. 1990, Pile \& Young 1999, Trask \& Van Dover 1999, Colaço et al. 2009, Riou et al. 2010a).

Studies of the Mid-Atlantic hydrothermal vent species B. azoricus Cosel \& Comtet, 1999 have provided strong evidence of the importance of trophic plasticity. It has been established that spatial variation in carbon

() The authors 2016. Open Access under Creative Commons by Attribution Licence. Use, distribution and reproduction are unrestricted. Authors and original publication must be credited.

Publisher: Inter-Research · www.int-res.com 
and nitrogen stable isotopes within the mussels is caused by differences in the proportions of thiotrophic versus methanotrophic symbionts, which are consistent with spatial differences in sulfide and methane availability (Trask \& Van Dover 1999, De Busserolles et al. 2009, Riou et al. 2010b).

Bathymodiolus childressi Gustafson, Turner, Lutz \& Vrijenhoek, 1998 is one of 4 members of the genus reported from Gulf of Mexico hydrocarbon seeps: $B$. childressi (depth range of 400 to $2200 \mathrm{~m}$ ), B. brooksi (1080 to $3300 \mathrm{~m}), B$. heckeri (2200 to $3300 \mathrm{~m})$, and an undescribed species (Faure et al. 2015). B. childressi is dominant at seep sites shallower than $1000 \mathrm{~m}$ and is generally considered to have only a single Type 1 methanotrophic symbiont, Gammaproteobacteria, within its gills (Duperron et al. 2007, Rodrigues et al. 2013). It has been well established that individuals assimilate proxy and natural particulate food in aquarium feeding experiments, but the extent to which such feeding contributes to overall nutrition is unknown (Page et al. 1990, Pile \& Young 1999).

The objective of the current study was to more fully evaluate trophic sources of $B$. childressi using $\mathrm{C}, \mathrm{N}$ and $\mathrm{S}$ stable isotope analyses of archived specimens. A large sample size $(n=253)$ from 2 distinctly different seep sites (Bush Hill and Brine Pool NR-1, hereafter referred to as Brine Pool) was used to allow for more powerful comparisons between seeps, within seeps and between sampling years. We used a 4 source mass-balance isotope mixing model to calculate source contributions and nutritional dependencies of the species. We were particularly interested in determining whether $B$. childressi can employ a mixed feeding strategy, involving particle feeding as well as dependence on endosymbiotic microbes.

Stable isotope measurements are reported in $\delta$ notation, that is to say, they are reported in standard notation as:

$$
\delta=\left[\left({ }^{\mathrm{H}} F /{ }^{\mathrm{L}} F\right)_{\text {sample }} /\left({ }^{\mathrm{H}} F /{ }^{\mathrm{L}} F\right)_{\text {standard }}-1\right] \times 1000
$$

where $\left({ }^{\mathrm{H}} F /{ }^{\mathrm{L}} F\right)$ is the fractional abundance of heavy and light isotopes of both the sample and the standard.

The values of $\delta^{13} \mathrm{C}, \delta^{15} \mathrm{~N}$ and less often $\delta^{34} \mathrm{~S}$ of $B$. childressi have been established in previous food web surveys (MacAvoy et al. 2002, 2005, Becker et al. 2013). Among-seep stable isotope variation has been analyzed at 4 upper slope $(<1000 \mathrm{~m})$ seeps including Bush Hill and Brine Pool (MacAvoy et al. 2008) and 7 lower slope (>1000 m) seeps (Becker et al. 2010). The overall ranges of $\delta^{13} \mathrm{C}$ and $\delta^{15} \mathrm{~N}$ are very broad, and there are distinct seep-specific patterns (Fig. 1). Both studies concluded that site-specific differences in carbon and nitrogen sources were the primary cause of this variation. $\delta^{13} \mathrm{C}$ values were explained as local mixtures of thermogenic with biogenic methane. The range of $\delta^{15} \mathrm{~N}$ values was attributed to locally variable ammonium concentrations and fractionations associated with ammonia usage (Lee \& Childress 1994, 1996, Lee et al. 1999). Seeps containing interstitial or pooling brine resulted in $\delta^{15} \mathrm{~N}$ values $<0 \%$. While the local-source explanation for the greatest amount of variation is probably correct, the possibility that multiple food sources also contributed to overall variation, as examined here, was not considered in those early studies.

\section{MATERIALS AND METHODS}

\section{Site selection}

The Bush Hill seep $\left(27.7811^{\circ} \mathrm{N}, 91.5082^{\circ} \mathrm{W}\right.$; Fig. 2) is an elongated topographic high with massive carbonate outcrops spanning a depth of 540 to $580 \mathrm{~m}$ along a fault adjacent to a salt diapir (MacDonald et al. 2003). Faunally, the site is dominated by dense assemblages of sulfide-dependent tubeworms with scattered smaller beds $\left(<10 \mathrm{~m}^{2}\right)$ of Bathymodiolus

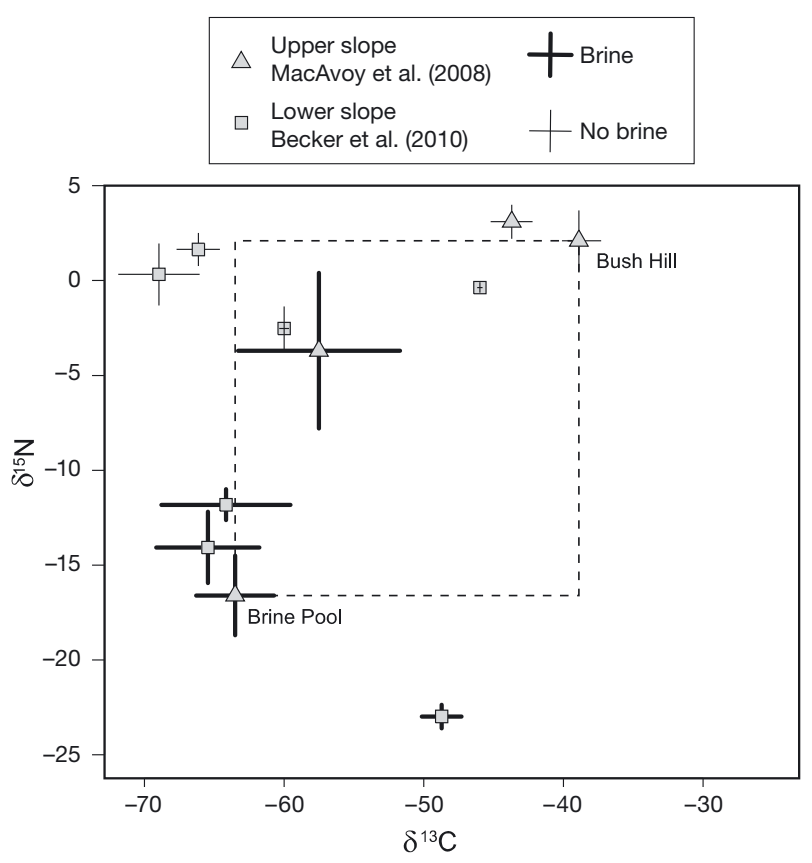

Fig. 1. Means and standard distribution of $\delta^{13} \mathrm{C}$ and $\delta^{15} \mathrm{~N}$ determined in previous sampling of Bathymodiolus childressi at 11 seeps in the northern Gulf of Mexico showing the high percent of reported ranges found in a comparison of just Bush Hill and Brine Pool 


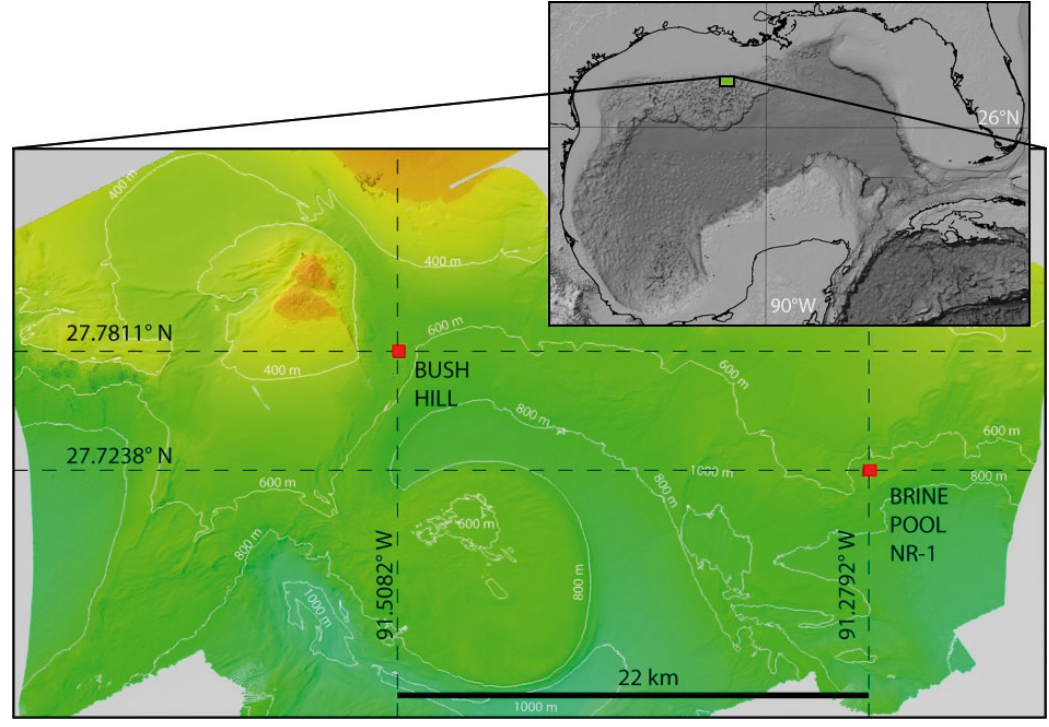

Fig. 2. Location of Bush Hill and Brine Pool seeps in the northern Gulf of Mexico

wide with an estimated contiguous surface area of $\sim 540 \mathrm{~m}^{2}$ (MacDonald et al. 1990). The ring is narrowest at the northern end of the pool and widest at the southern, where the brine discharges down slope. Tubeworms are absent from the mussel ring and the adjacent seafloor. Methane collected from various parts of the pool habitat has a biogenic origin based on both isotopic value and paucity of heavier hydrocarbon gases (Bernard et al. 1978, Whiticar 1999). Bubbles collected above the brine had methane $\delta^{13} \mathrm{C}$ values with an average of $-63.8 \%$ and only trace amounts of $\mathrm{C}_{1}-\mathrm{C}_{3}$ hydrocarbons (MacDonald et al. 1990). A similar $\delta^{13} \mathrm{C}$ value of $-66 \%$ was found for brine-dissolved methane (Joye et al. 2005). Mussel tissue values $\left(\delta^{13} \mathrm{C}\right.$

childressi. Bush Hill seepage includes both liquid petroleum and gas (bubbles, dissolved and hydrates). Sassen et al. (1999) reported bubble and hydrate methane $\delta^{13} \mathrm{C}$ values of $-43 \%$ as well as significant amounts of $\mathrm{C}_{2}-\mathrm{C}_{3}$ gases indicative of thermogenic origin and leakage from hydrocarbon reservoirs (Bernard et al. 1978, Whiticar 1999). Previous analyses of mussel tissue values at Bush Hill were consistent with utilization of local methane (tissue $\delta^{13} \mathrm{C}$ mean $=-38.9 \%$, $n=7$; MacAvoy et al. 2008). The spatial and temporal variability of methane flux within the larger Bush Hill site has been demonstrated through seafloor monitors (Tryon \& Brown 2004) and models of the underlying hydrate system (Chen \& Cathles 2003). Dissolved sulfide appears to be largely consumed within the sediment by the tubeworm populations (Cordes et al. 2003). Concentrations of sulfide within mussel patches and at the sediment-water interface have been reported as undetectable or very low (MacDonald et al. 1990, Nix et al. 1995).

The Brine Pool $\left(27.7238^{\circ} \mathrm{N}, 91.5082^{\circ} \mathrm{W}\right.$; Fig. 2) and its $B$. childressi population are distinctly different. Currently interpreted as a brine-filled mud volcano at a depth of $650 \mathrm{~m}$ (MacDonald \& Peccini 2009), the pool contains a $130 \%$ salinity sulfate-free brine originating from seawater contact with massive halite within the seafloor (MacDonald et al. 1990, Dattagupta et al. 2004, Joye et al. 2005). This and other seep-associated brine pools may represent very large reservoirs of dissolved methane (Wankel et al. 2010). A continuous mat of mussels rings the pool 3 to $7 \mathrm{~m}$ mean $=-63.5 \%$, $\mathrm{n}=8$ ) at Brine Pool are consistent with utilization of local methane (MacAvoy et al. 2008). The brine itself lacks the sulfate needed for microbial generation of sulfide (Joye et al. 2005). Brine diluted by seawater under the mussels did contain sulfide at higher concentrations near the pool, but no sulfide was detected in the normal seawater just a few cm higher.

Archived specimens from the Bush Hill and Brine Pool seeps were selected from a collection at Louisiana State University for study on the basis of 2 criteria. Firstly, they were known to provide strong contrasts in stable isotope values $\left(82 \%\right.$ of the $\delta^{13} \mathrm{C}$ and $72 \%$ of the $\delta^{15} \mathrm{~N}$ range of seep means reported for the Gulf of Mexico specimens). Secondly, the conditions for population maintenance have been shown to be different at Brine Pool, which provides the better environment based on mussel size and condition (Nix et al. 1995, Smith et al. 2000). The cause of the better conditions at Brine Pool is considered to be primarily associated with a greater exposure to methane (Bergquist et al. 2004).

\section{Sampling design}

In this study, we examined 253 specimens. Of those, 207 were collected between 1989 and 1992 for a study of spatial differences in species composition in mussel-dominated seep assemblages (Carney 1994). Brine Pool samples were collected during Johnson Sea Link I Dives 2598, 3145 and Sea Link II 
Dive 3521. Bush Hill samples were collected during Sea Link I Dives 3139, 3269 and 3274. The Sea Link submersibles were operated by Harbor Branch Oceanographic Institute onboard either the R/V 'Seward Johnson' or 'Edwin Link'. Samples consisted of 25 separate scoops of mussels and associated organisms taken with the hydraulic scoop of the Johnson Sea Link submersible. Specimens collected between 1989 and 1992 were preserved in a $5 \%$ seawater formalin using the same lot of Fisher F79-4 formaldehyde stabilized with methanol, and maintained in archival storage without change of preservative. During the years of sampling, the submersible lacked precision on-bottom navigation, making the exact location of samples known only by dead reckoning. At Bush Hill, 3 beds (designated 1, 1a and 2) were sampled at an edge and in the interior. Beds 1 and 1a had only a poorly defined boundary between them; Bed 2 was entirely separate. At the continuous mussel ring of the Brine Pool, spatial differences were sought by sampling the north and south ends of the pool at the inner edge in contact with the brine and the outer edge in contact with the mud bottom. In an early study, the species composition of $B$. childressi beds at both sites was found to be remarkably uniform without major spatial differences (Carney 1994). Spatial patterns of mussel trophic status were not examined at that time. A second sampling only at the Brine Pool was carried out in 2006, yielding 46 specimens from the north and south end of the pool. Four scoops of mussels were taken from an area of approximately $9 \mathrm{~m}^{2}$, thus pooling the edge and inner areas. While lacking the spatial design of the earlier sampling, these more recent specimens were analyzed for possible temporal differences. The 2006 specimens were also preserved and stored in 5\% seawater formalin using EMD FX0410-1 formaldehyde.

\section{Sample preparation and isotope analysis}

In 2010, mussel specimens were selected from the archive for trophic analysis. To minimize the confounding effects of size and spatial/temporal effects, a full within-sample size range of specimens was selected. Mussel lengths and single-valve height were measured to the nearest $\mathrm{mm}$. Specimens were opened and washed in deionized water for up to $24 \mathrm{~h}$ to dilute and remove seawater salt, sulfate, and unbound formaldehyde. To avoid inclusion of symbiont microbes (which have been reported from the gills, mantle, and foot; Streams et al. 1997), tissue from the large adductor muscle was used for isotope analysis. The tissues were dried at $60^{\circ} \mathrm{C}$ for a minimum of $12 \mathrm{~h}$, processed to a fine powder using a WIG-L-BUG (Dentsply International), and 5 to $8 \mathrm{mg}$ loaded for analysis. Carbon, nitrogen and sulfur (CNS) analysis was done following the methods of Fry (2007). Values are reported for $\delta^{13} \mathrm{C}$ values versus PeeDee Belemnite, for $\delta^{15} \mathrm{~N}$ values versus atmospheric nitrogen, and for $\delta^{34} \mathrm{~S}$ values versus Canyon Diablo Troilite. The $95 \%$ confidence level for these analyses is $0.1 \%$ for both $\delta^{13} \mathrm{C}$ and $\delta^{15} \mathrm{~N}$, and $0.4 \%$ for $\delta^{34} \mathrm{~S}$. Laboratory standards with a range of weights and duplicates were interspersed with samples to ensure consistency. Formaldehyde preservation can affect $\delta^{13} \mathrm{C}$ values, and corrections ranging from -1.1 to $0.4 \%$ were made to raw data (see the Supplement at www.int-res.com/articles/suppl/m547p091_supp. pdf). However, the corrections were small compared to the measured $\delta^{13} \mathrm{C}$ range of -36.2 to $-77.4 \%$.

\section{Proportional trophic mixing analysis}

When the isotopic content of an organism is expressed as the mixture of fractional contributions from multiple sources that sum to one, the estimation of those contributions provides a useful means of data analysis and ecological interpretation (Phillips 2012). The computational requirements for these mixing models are that each individual isotopic value is modeled as a series of linear equations (Fry 2013). For 4 sources, these equations are:

$$
\begin{gathered}
f_{1}+f_{2}+f_{3}+f_{4}=1 \\
f_{1} \times \delta_{1} \text { Source } 1+f_{2} \times \delta_{1} \text { Source } 2+f_{3} \times \\
\delta_{1} \text { Source } 3+f_{4} \times \delta_{1} \text { Source } 4=\delta_{1} \text { Sample } \\
f_{1} \times \delta_{2} \text { Source } 1+f_{2} \times \delta_{2} \text { Source } 2+f_{3} \times \\
\delta_{2} \text { Source } 3+f_{4} \times \delta_{2} \text { Source } 4=\delta_{2} \text { Sample } \\
f_{1} \times \delta_{3} \text { Source } 1+f_{2} \times \delta_{3} \text { Source } 2+f_{3} \times \\
\delta_{3} \text { Source } 3+f_{4} \times \delta_{3} \text { Source } 4=\delta_{3} \text { Sample }
\end{gathered}
$$

where $f_{i}$ is the fractional contribution of each source, $i=1,2,3,4$. Since there are 4 unknown fractional contributions and 4 equations, a unique solution is reached for all samples that fall within the mixing tetrahedron vertices formed by the 4 sources. Obtaining those solutions using linear algebra requires first that a square matrix of isotope composition (i.e. CNS) of the sources be established, inverted and multiplied by a rectangular matrix of sample isotope values. These calculations were carried out in Excel (Microsoft) using the built-in array functions MINVERSE and MMULT. 
There are various approaches for the establishment of the trophic resources reflected in tissue samples. Here, we followed the approach of Wissel et al. (2005) and Fry (2013), combining existing knowledge of likely environmental sources in conjunction with sources inferred from the pattern of isotope values and consistent with the ecology of B. childressi. Geometrically, the 4 sources define the vertices of a tetrahedron or pyramid in a Cartesian space with the orthogonal axes $\delta^{13} \mathrm{C}, \delta^{15} \mathrm{~N}$ and $\delta^{34} \mathrm{~S}$. All samples that are a mixture of the sources lie within that tetrahedron. Estimation of sources requires adjusting the initial vertices until a tetrahedron is developed that contains all sample points. This iterative process of tetrahedron adjustment began with a 2-dimensional examination of each isotope pair, followed by a refinement of the location of vertices in a 3-dimensional view using OriginPro 8.6 (OriginLabs).

Repeated iterations of our trial and error process for constructing tightly fitting mixing models yielded similar results, so that the presented mixing models encompassed the measured data in a highly reproducible way. However, we recognize that we may have oversimplified the mixing dynamics by considering only 4 sources and cannot eliminate the possibility that there are more sources. Recognizing this limitation, our 4-source mixing models implicitly aggregate or collapse any additional sources into our 4 identified sources. Source values represent values predicted for animals that are $100 \%$ dependent on foods and include any diet-animal fractionations between animals and their food.

\section{RESULTS}

\section{Single isotope characteristics}

Determination of $\delta^{13} \mathrm{C}, \delta^{15} \mathrm{~N}$ and $\delta^{34} \mathrm{~S}$ values were made for 125 specimens from Bush Hill and 128 specimens at Brine Pool, with the latter divided into 82 specimens for the 1989 to 1991 samplings and 46 specimens for the 2006 sampling. Data interpretation employed descriptive statistics and kernel density plots, which display data as a continuous function rather than the discontinuous bins of histograms (Bowman \& Azzalini 2013). Kernel density plots (Fig. 3) and descriptive statistics (Table 1) revealed significant differences in sample means and sample populations. Values of $\delta^{34} \mathrm{~S}$ (Fig. 3) had a multimodal distribution at Bush Hill, but well-defined single modes and negative skew in Brine Pool samples. Somewhat the opposite was found for $\delta^{13} \mathrm{C}$ values
(Table 1a, Fig. 3). At Bush Hill, $\delta^{13} \mathrm{C}$ displayed a wellformed single mode, narrow range, and some negative skew. In the Brine Pool 1989 to 1991 samples, a tail of $\delta^{13} \mathrm{C}$ values between -60 and $-80 \%$ was evident. At Brine Pool 2006, the population was bi- or
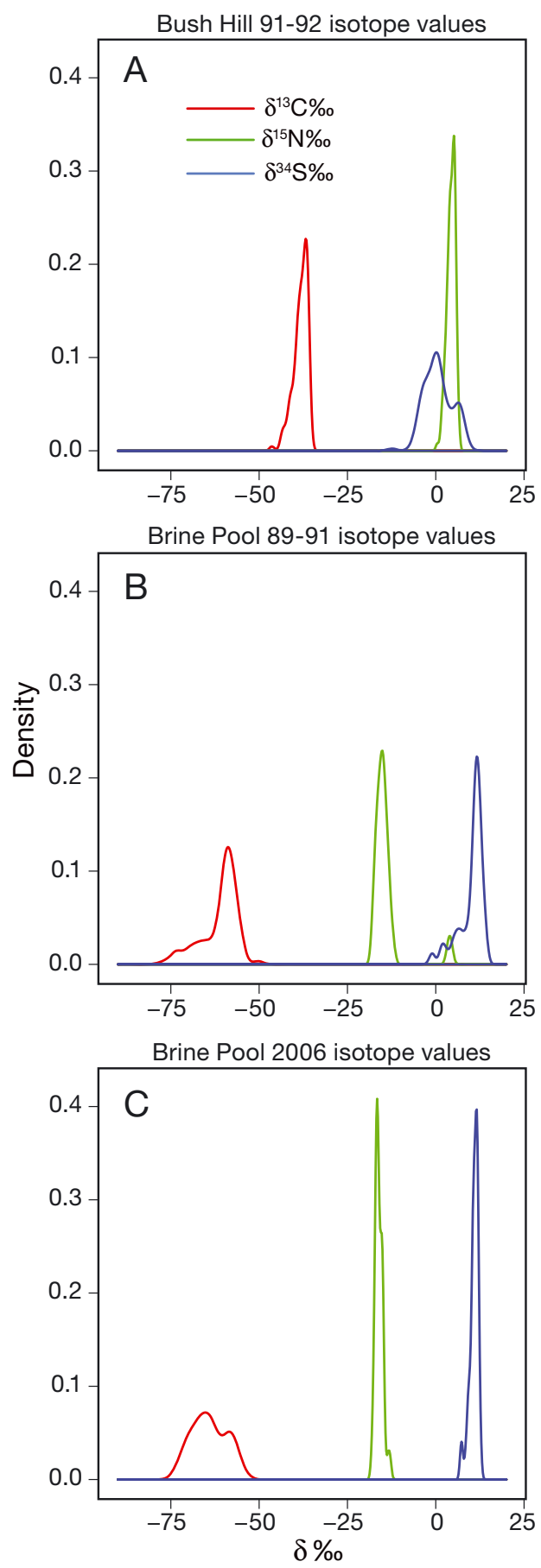

Fig. 3. Kernel density plots (Bowman \& Azzalini 2013) of stable isotope values from Bathymodiolus childressi tissue for (A) all Bush Hill specimens collected in 1991 and 1992, (B) Brine Pool specimens collected between 1989 and 1991 and (C) Brine Pool specimens collected in 2006 
Table 1. (a) Descriptive statistics and (b) $t$-tests of equal means between seeps for Bathymodiolus childressi isotope parameters and calculated trophic resources. SM: symbiotic-methanotrophic pathways for Bush Hill $\left(\mathrm{A}_{\mathrm{BH}}\right.$ and $\left.\mathrm{B}_{\mathrm{BH}}\right)$ and $\mathrm{Brine}$ Pool $\left(\mathrm{C}_{\mathrm{BP}}\right.$ and $\left.\mathrm{D}_{\mathrm{BP}}\right)_{i} \mathrm{DPHY}$ : detrital source from phytoplankton; DSOM: detrital source of thiotrophic-microbe sulfide oxidation

\begin{tabular}{|c|c|c|c|c|c|c|c|c|}
\hline \multicolumn{9}{|c|}{ (a) Site descriptive statistics } \\
\hline & $\begin{array}{l}\text { Shell length } \\
\text { (cm) }\end{array}$ & $\delta^{15} \mathrm{~N}$ & $\delta^{13} \mathrm{C}$ & $\delta^{34} \mathrm{~S}$ & SM_A $A_{B H}$ & SM_B B & DPHY & $\mathrm{DSOM}_{\mathrm{BH}}$ \\
\hline \multicolumn{9}{|c|}{ Bush Hill 1991-1992 $(\mathrm{n}=125)$} \\
\hline Mean & 6.81 & 4.3 & -38.3 & 0.7 & 0.24 & 0.22 & 0.16 & 0.38 \\
\hline SD & 1.65 & 1.2 & 2.04 & 3.9 & 0.07 & 0.10 & 0.05 & 0.13 \\
\hline Skewness & -0.33 & -0.7 & -1.2 & 0.0 & -0.28 & 0.66 & 0.31 & -0.32 \\
\hline Kurtosis & -0.56 & 0.1 & 1.3 & -0.2 & 0.22 & 0.10 & 0.04 & -0.61 \\
\hline Minimum & 2.7 & 0.4 & -46.4 & -12.4 & 0.01 & 0.05 & 0.04 & 0.11 \\
\hline Maximum & 9.8 & 6.4 & -35.7 & 9.0 & 0.39 & 0.55 & 0.29 & 0.68 \\
\hline \multirow[t]{2}{*}{ Range } & 7.1 & 6.0 & 10.0 & 21.4 & 0.37 & 0.50 & 0.25 & 0.58 \\
\hline & $\begin{array}{l}\text { Shell length } \\
\qquad(\mathrm{cm})\end{array}$ & $\delta^{15} \mathrm{~N}$ & $\delta^{13} \mathrm{C}$ & $\delta^{34} \mathrm{~S}$ & SM_C & SM_D ${ }_{B P}$ & DPHY & $\mathrm{DSOM}_{\mathrm{BP}}$ \\
\hline \multicolumn{9}{|c|}{ Brine Pool 1989-1991 $(n=82)$} \\
\hline Mean & 8.86 & -14.1 & -61.1 & 10.0 & 0.13 & 0.47 & 0.21 & 0.19 \\
\hline $\mathrm{SD}$ & 2.49 & 4.82 & 5.24 & 3.5 & 0.16 & 0.13 & 0.07 & 0.06 \\
\hline Skewness & -0.45 & 3.12 & -0.62 & -1.5 & 2.93 & -1.82 & -0.75 & -0.45 \\
\hline Kurtosis & -0.93 & 8.99 & -0.45 & 1.5 & 8.12 & 3.76 & 0.29 & 1.38 \\
\hline Minimum & 3.0 & -17.8 & -77.0 & -1.1 & 0.01 & 0.02 & 0.01 & 0.01 \\
\hline Maximum & 12.9 & 4.4 & -50.5 & 13.9 & 0.73 & 0.65 & 0.36 & 0.33 \\
\hline \multirow[t]{2}{*}{ Range } & 9.9 & 22.2 & 26.8 & 15.0 & 0.72 & 0.63 & 0.35 & 0.32 \\
\hline & $\begin{array}{l}\text { Shell length } \\
\text { (cm) }\end{array}$ & $\delta^{15} \mathrm{~N}$ & $\delta^{13} \mathrm{C}$ & $\delta^{34} \mathrm{~S}$ & SM_C & SM_D ${ }_{B P}$ & DPHY & $\mathrm{DSOM}_{\mathrm{BP}}$ \\
\hline \multicolumn{9}{|c|}{ Brine Pool $2006(n=46)$} \\
\hline Mean & 8.65 & -16.1 & -64.4 & 10.8 & 0.10 & 0.53 & 0.18 & 0.19 \\
\hline SD & 2.82 & 1.02 & 4.83 & 1.2 & 0.05 & 0.05 & 0.07 & 0.03 \\
\hline Skewness & -0.26 & 0.78 & 0.10 & -1.2 & 1.04 & -0.46 & -0.45 & 0.00 \\
\hline Kurtosis & -0.98 & 0.62 & -1.13 & 1.3 & 0.79 & -0.88 & -0.21 & -0.78 \\
\hline Minimum & 2.9 & -18.0 & -72.5 & 7.2 & 0.03 & 0.42 & 0.01 & 0.13 \\
\hline Maximum & 13.1 & -12.9 & -55.0 & 12.6 & 0.23 & 0.62 & 0.31 & 0.24 \\
\hline Range & 10.2 & 5.05 & 17.5 & 5.4 & 0.20 & 0.21 & 0.30 & 0.11 \\
\hline \multicolumn{9}{|c|}{ (b) Between-seep and between-times at Brine Pool comparisons: $t$-test of equal means for combined methane sources } \\
\hline \multicolumn{9}{|c|}{ Between both seeps (2006 omitted) } \\
\hline$t$ & 6.5938 & 33.9449 & 37.6748 & 17.89 & \multicolumn{2}{|c|}{9.56} & 6.67 & 14.82 \\
\hline p-value & $<0.00001$ & $<0.00001$ & $<0.00001$ & $<0.00001$ & \multicolumn{2}{|c|}{$<0.00001$} & $<0.00001$ & $<0.00001$ \\
\hline \multicolumn{9}{|c|}{ Between 1989 and 1991 Brine Pool vs. 2006 Brine Pool } \\
\hline$t$ & 0.4368 & 3.651 & 3.2226 & 1.9379 & -1.68 & 3.82 & -2.49 & 0.003 \\
\hline p-value & 0.6633 & 0.0004304 & 0.001717 & 0.0552 & 0.0964 & 0.0002 & 0.01 & 0.99 \\
\hline
\end{tabular}

multimodal with separation occurring at ca. $-60 \%$. Values of $\delta^{15} \mathrm{~N}$ had a well-formed single-mode population in each of the 3 seep groups, with the exception of 5 outlier data points.

The 5 outlier $\delta^{15} \mathrm{~N}$ values (Fig. 3B) came from mussels from a single scoop sample collected in 1991 from the northern edge of Brine Pool, and appear to reflect the existence of small patches of distinctive specimens. The 1991 Brine Pool outlier $\delta^{15} \mathrm{~N}$ values were similar to those of Bush Hill mussels; however, the possibility of a site-of-collection error in the field or in the archive could be ruled out on the basis of the other isotopes. Values of $\delta^{13} \mathrm{C}$ and $\delta^{34} \mathrm{~S}$ for the $5 \mathrm{spec}-$ imens were somewhat distinctive but fell within the range of the Brine Pool 1989 to 1991 samples. Their average $\delta^{13} \mathrm{C}$ value (-55.3\%) fell in the less depleted tail of the distribution, while their average $\delta^{34} \mathrm{~S}$ value $(0.7 \%$ o fell in the more depleted tail. The outliers 
cannot be experimentally transplanted Bush Hill specimens because between-seep transplanting of well-marked mussels was not initiated until 1994 (Dattagupta et al. 2004). Therefore, the outliers were retained in the data for mixing analysis.

Pooling specimens within each seep, the means of all 3 isotopes were found to be significantly different in a comparison of the 1989 to 1991 Brine Pool and the 1991 and 1992 Bush Hill (Table 1b). There were no overlapping values of tissue $\delta^{13} \mathrm{C}$ between seeps, with the mean at Bush Hill being much more enriched $(-38.3 \pm 2 \%)$ than at Brine Pool $(-61.1 \pm$ $5.2 \%$ ). With the exception of the 5 outliers, $\delta^{15} \mathrm{~N}$ values were also completely separate, with the mean at Bush Hill being more enriched $(4.3 \pm 1.2 \%$ ) than that found at Brine Pool $\left(-14.1 \pm 4.8 \%\right.$ o). For $\delta^{34} \mathrm{~S}$ values there was an overlap of range, but the means were distinct. Bush Hill had a more depleted mean $(0.7 \pm$ $1.2 \%$ ) than Brine Pool $(10 \pm 3.5 \%)$. These results are consistent with previous comparisons based on smaller sample sizes (Nix et al. 1995, Smith et al. 2000, Dattagupta et al. 2004).

CNS isotope values were significantly correlated (see Table S2 in the Supplement). Values of $\delta^{13} \mathrm{C}$ and $\delta^{15} \mathrm{~N}$ were always positively correlated, ranging from the lowest value $(r=0.48)$ in the Brine Pool 1989 to 1991 samples to the highest value at Brine Pool 2006 $(\mathrm{r}=0.86)$. Values of $\delta^{13} \mathrm{C}$ and $\delta^{34} \mathrm{~S}$ were not significantly correlated in Brine Pool 2006 samples but were significant and negative in Brine Pool 1989 to $1991(\mathrm{r}=-0.40)$ and Bush Hill $(\mathrm{r}=-0.75)$ samples. Values of $\delta^{34} \mathrm{~S}$ and $\delta^{15} \mathrm{~N}$ were not significantly correlated at Brine Pool 2006 but significant and negatively correlated at Brine Pool 1989 to $1991(\mathrm{r}=-0.75)$ and Bush Hill $(r=-0.55)$. Significant correlations are not proof per se that isotopes were assimilated as linked in foods and resources, but would be consistent with such linkages.

\section{Estimation of 4-resource proportional mixing}

The isotope values we report here are consistent with a multi-source trophic structure for the mussel populations on the basis of 3 criteria. First, while inherent variabilities of $\delta^{13} \mathrm{C}, \delta^{15} \mathrm{~N}$ and $\delta^{34} \mathrm{~S}$ given a single-source uniform diet have not been established for these mussels, the large SD variation found for all mussel isotope data (Table 1a) supports the contention that mussel nutrition is multi-sourced (Barnes et al. 2008). Second, multi-modal and skewed distributions are consistent with multiple sources. Third, the significance of correlations among isotopes pro- vides support for the contention that they are obtained in linked combinations from those multiple resources rather than being obtained independently.

The sources (tetrahedron vertices) for the mixing model were chosen on the basis of (1) feasibility in the incompletely known upper continental slope seep geochemical setting (Table 2) and (2) the degree to which their values allowed for the tightest fit of the mixing tetrahedron around the sample data. As anticipated from the between-seep stable isotope differences, each seep required estimation of separate sets of sources (Fig. 4), and Bush Hill and Brine Pool displayed distinctly different patterns of resource utilization (Fig. 5). Each seep consisted of 2 different symbiotic methanotrophic (SM) pathways: SM_A $A_{B H}$ and SM_B $B_{B H}$ at Bush Hill, and SM_C $C_{B P}$ and SM_D $D_{\mathrm{BP}}$ at Brine Pool. Each seep also had a single but distinctive source consistent with a detrital sulfide-oxidation (DSOM) pathway that may represent thiotrophic-microbe sources $\mathrm{DSOM}_{\mathrm{BH}}$ and $\mathrm{DSOM}_{\mathrm{BP}}$, respectively. The 2 tetrahedrons had one source in common, representing a ubiquitous detrital source derived from phytoplankton (DPHY). A schematic representation of the isotope contribution to trophic sources is presented in Fig. 6.

Use of a single DPHY source at both seeps is consistent with the expectation that the labile component of detritus influx from euphotic zone phytoplankton is essentially the same at the closely located, similar depth seeps (Biggs et al. 2008). DPHY has a $\delta^{13} \mathrm{C}$ value of $-21.5 \%$ and a $\delta^{15} \mathrm{~N}$ value of $7 \%$, which is representative of surface particulate organic matter in the northern Gulf of Mexico (Rooker et al. 2006, Wells \& Rooker 2009), and a $\delta^{34} \mathrm{~S}$ value of $21 \%$, representative of seawater sulfate (Rees et al. 1978).

There are several microbial species at seep sites that may contribute to a free-living thiotrophic detritus source (Orcutt et al. 2005), but they have not been characterized isotopically. In this study the large and easily sampled microbe Beggiotoa, which is present at both seeps, was used as a proxy. The $\delta^{13} \mathrm{C}$ value $-31 \%$ assigned to both $\mathrm{DSOM}_{\mathrm{BH}}$ and $\mathrm{DSOM}_{\mathrm{BP}}$ falls within the range of values reported from 27 analyses of box core samples taken in non-brine Gulf of Mexico seep areas by Demopoulos et al. (2010). In that study, the range of $\delta^{15} \mathrm{~N}$ values was -6.8 to $5.1 \%$. In our analysis, however, a slightly enriched $\delta^{15} \mathrm{~N}$ of $7 \%$ for $\mathrm{DSOM}_{\mathrm{BH}}$ was used providing a good tetrahedron fit consistent with incorporation of seawater nitrate (5 to $7 \%$ ) by the microbes. $\mathrm{DSOM}_{\mathrm{BP}}$ was assigned a $\delta^{15} \mathrm{~N}$ value of $-25 \%$, which is consistent with microbial utilization of brine-associated ammonium. For 
Table 2. Literature-derived values for isotope compositions and fractionations for the Gulf of Mexico cold seep environments and proxies. $\varepsilon$ is the isotopic fractionation factor in \%, approximately the difference between product and source isotope values, associated with the listed processes

\begin{tabular}{|c|c|c|c|c|c|c|}
\hline Sources & $\begin{array}{l}\delta^{13} \mathrm{C} \\
(\%)\end{array}$ & $\begin{array}{c}\delta^{15} \mathrm{~N} \\
(\% \circ)\end{array}$ & $\begin{array}{l}\delta^{34} \mathrm{~S} \\
(\% \mathrm{o})\end{array}$ & $\begin{array}{l}\delta^{2} \mathrm{H} \\
(\% \circ)\end{array}$ & $\begin{array}{c}\varepsilon \\
(\%)\end{array}$ & References \\
\hline $\mathrm{CH}_{4}$ at Brine Pool & -63.8 & & & $-165,-200$ & & Sassen et al. (1999) \\
\hline $\mathrm{CH}_{4}$ at Bush Hill & -45.4 & & & -178 & & Sassen et al. (2004) \\
\hline $\begin{array}{l}\mathrm{CH}_{4} \rightarrow \delta^{13} \mathrm{C}_{\text {Biomass }} \text { (type-I methanotroph, pure culture } \\
\text { Methylomonas methanica) }\end{array}$ & & & & & $-15,-25$ & Templeton et al. (2006) \\
\hline Particulate organic matter, Gulf of Mexico surface & -21.5 & 2.8 & & & & Wells \& Rooker (2009) \\
\hline Marine particulate organic matter, general & -22 & & 21 & & & Peterson \& Fry (1987) \\
\hline Bottom water nitrate & & $5-7$ & & & & Liu \& Kaplan (1989) \\
\hline $\mathrm{NH}_{4}{ }^{+} \rightarrow \delta^{15} \mathrm{~N}_{\text {Biomass }}$ (pure culture Vibrio harveyi) & & & & & -14 to -27 & Hoch et al. (1992) \\
\hline Sulfur-oxidizing microbial biomass (field-sampled Beggiatoa sp.) & -31 & -2.5 & & & & Demopoulos et al. (2010) \\
\hline Seawater $\mathrm{SO}_{4}^{2-}$ & & & 21 & & & Rees et al. (1978) \\
\hline $\mathrm{H}_{2} \mathrm{~S}$, Bush Hill sediment (2 cm core depth) & & & 12.1 & & & $\mathrm{Fu}(1998)$ \\
\hline $\mathrm{SO}_{4}{ }^{2-} \rightarrow \mathrm{H}_{2} \mathrm{~S}$ Bush Hill range of microbial reduction in sediment & & & & & -9 to -15 & Aharon \& Fu (2000) \\
\hline $\mathrm{SO}_{4}{ }^{2-} \rightarrow \mathrm{H}_{2} \mathrm{~S}$ global range of microbial reduction in sediment & & & & & -8 to -77 & $\begin{array}{l}\text { Canfield (2001), } \\
\text { Wortmann et al. (2001) }\end{array}$ \\
\hline
\end{tabular}

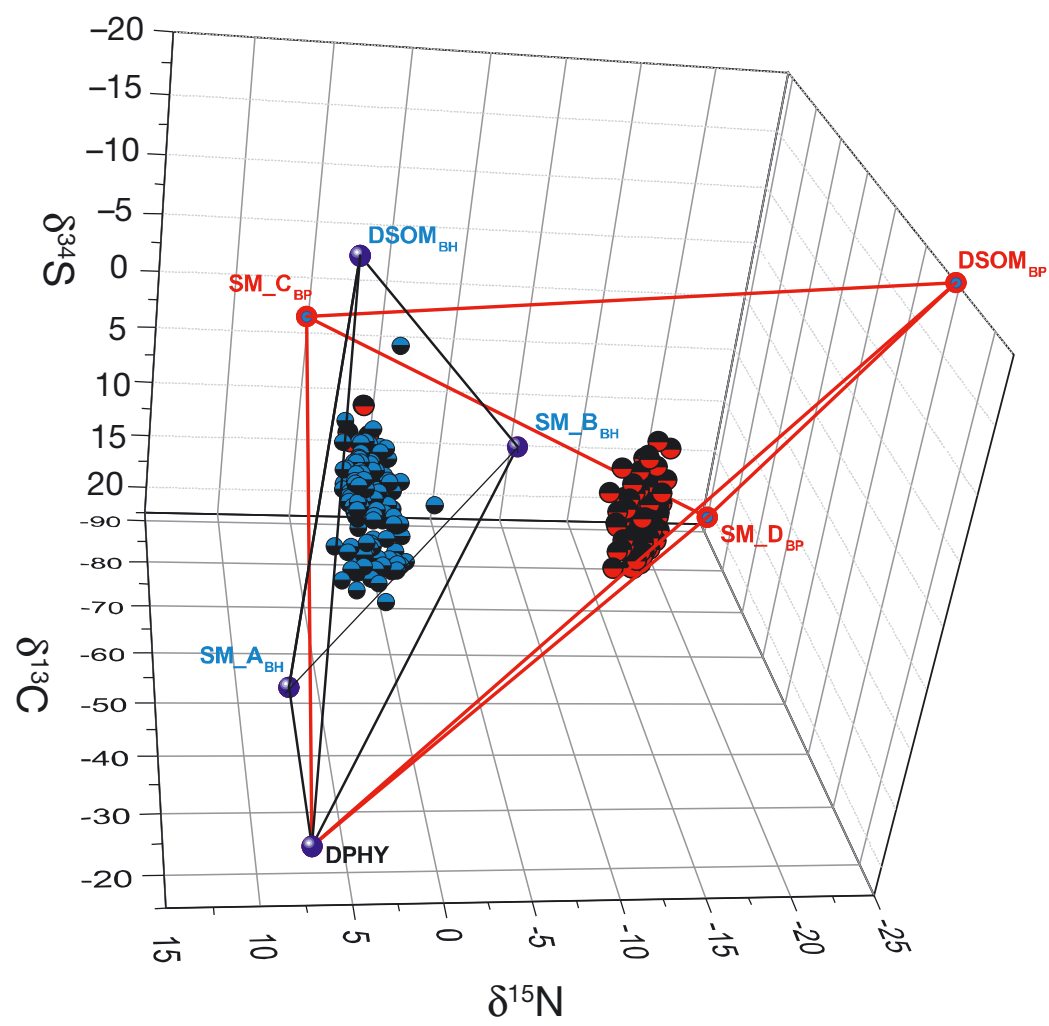

Fig. 4. Graphical representation of 3-dimensional tetrahedrons fitted around data points with the vertices representing trophic sources as inferred from Bathymodiolus childressi isotope variation and the isotopic values of seepsystem components. See Table 1 for description of abbreviations
$\mathrm{DSOM}_{\mathrm{BP}}$, the tetrahedron fit required a $\delta^{34} \mathrm{~S}$ value of $-20 \%$, consistent with incorporation of sulfur from microbial sulfur cycling (Canfield 2001, Dale et al. 2009).

Two methane sources were estimated for each seep. At Bush Hill, the narrow range and symmetry of $\delta^{13} \mathrm{C}$ values (Fig. 3A) were consistent with 2 food sources (SM_A $A_{B H}$ and SM_B $B_{B H}$ ), both based on a single methane pool with a $\delta^{13} \mathrm{C}$ value of $-50 \%$. The first methane-derived source, SM_A $A_{B H}$, combines seep methane carbon with seawater sources of nitrogen and sulfur $\left(\delta^{15} \mathrm{~N}=7 \%\right.$; $\delta^{34} \mathrm{~S}=20 \%$ o). SM_B $\mathrm{BH}$ has seep-influenced nitrogen and sulfur with modest depletions of $\delta^{15} \mathrm{~N}$ $\left(-5 \%\right.$ ) and $\delta^{34} \mathrm{~S}(0 \%$ o) compared to SM_A $A_{B H}$, and may reflect a mixture of sediment-derived seepage.

At the Brine Pool, $\delta^{13} \mathrm{C}$ bimodality and asymmetry (Fig. 3B) along with tetrahedral fit (Fig. 3) are best explained by 2 methane-derived sources $\left(\mathrm{SM} \mathrm{C}_{\mathrm{BP}}\right.$ and $\mathrm{SM}_{-} \mathrm{D}_{\mathrm{BP}}$ ) being composed of carbon from 2 separate methane pools. SM_C $\mathrm{BP}_{\mathrm{BP}}$ combines moderately depleted carbon $\left(\delta^{13} \mathrm{C}=\right.$ 

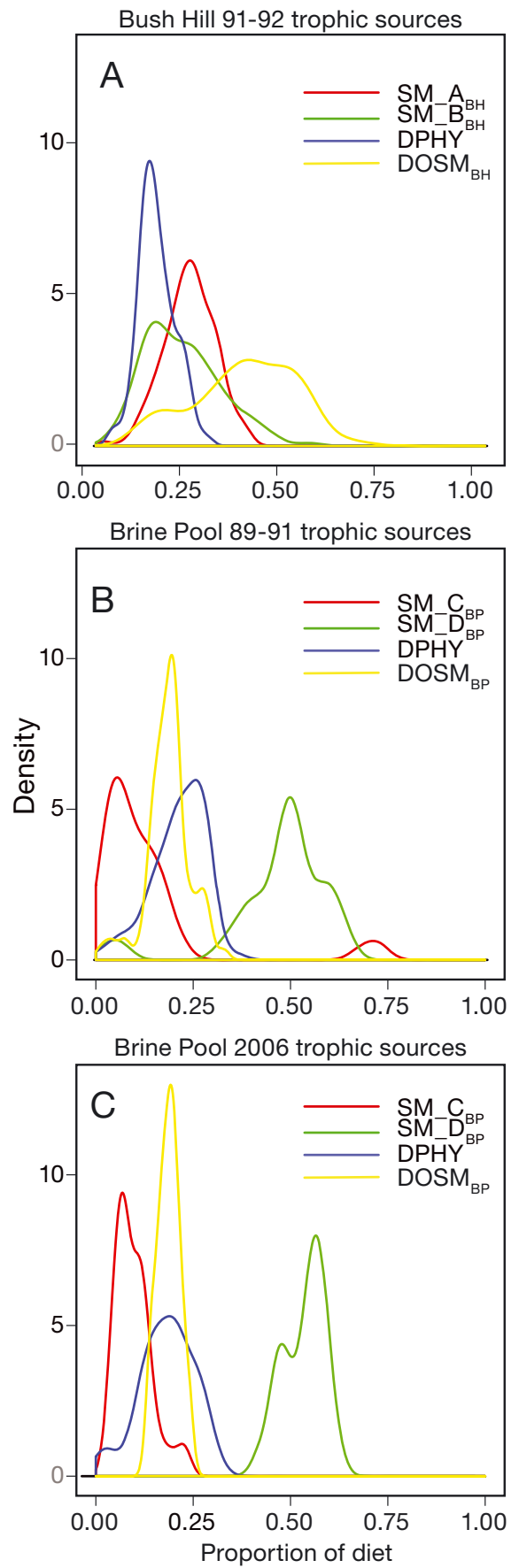

Fig. 5. Kernel density plots (Bowman \& Azzalini 2013) of proportion of 4 trophic resources from Bathymodiolus childressi tissue for (A) all Bush Hill specimens collected in 1991 and 1992, (B) Brine Pool specimens collected between 1989 and 1991 and (C) Brine Pool specimens collected in 2006.

See Table 1 for description of abbreviations

$-65 \%$ ) with nitrogen from seawater nitrate $\left(\delta^{15} \mathrm{~N}=\right.$ $7 \%$ ) and sulfur from seep sulfide $\left(\delta^{34} \mathrm{~S}=-5 \%\right)$. SM_D $D_{\text {BP }}$ combines highly depleted carbon $\left(\delta^{13} \mathrm{C}=\right.$ $-90 \%$ ) with highly depleted nitrogen from seep ammonium $\left(\delta^{15} \mathrm{~N}=-25 \%\right)$ and sulfur from seawater sul- fate $\left(\delta^{34} \mathrm{~S}=21 \%\right.$ ). These Brine Pool methane sources are not readily separated into sediment vs. watercolumn sources but seem to indicate different types of sediment sources, one with reduced ammonium $\mathrm{N}$ and the other with reduced sulfide $\mathrm{S}$.

\section{Between-seep comparisons}

Paired $t$-tests between seeps (Table $1 \mathrm{~b}$ ) indicated significant differences between Brine Pool and Bush Hill in average utilization of the 3 source categories of methane-derived sources $\left(\mathrm{SM}_{-} \mathrm{A}_{\mathrm{BH}}+\mathrm{SM} \mathrm{B}_{\mathrm{BH}} \mathrm{vs}\right.$. SM_C $\left.C_{B P}+S M \_D_{B P}\right)$, sulfur-microbe sources $\left(D_{S O M} M_{B H}\right.$ vs. $\mathrm{DSOM}_{\mathrm{BP}}$ ) and the phytoplankton source (DPHY). The mussel population at the Brine Pool made significantly greater use of combined methane-pathway sources (mean $\pm \mathrm{SD}$ : $61.1 \pm 9.3 \%$ ), predominantly SM_D $D_{\text {BP }}(49.4 \pm 11.5 \%)$, and lower and roughly equal particulate resources DPHY $(20.2 \pm 7.0 \%)$ and $\operatorname{DSOM}_{\mathrm{BP}}(18.7 \pm 4.7 \%)$. At Bush Hill, the use of combined methane-pathway resources was significantly lower in the population $(46.2 \pm 11.1 \%)$ and consisted of roughly equal amounts of SM_A $A_{B H}(24.0 \pm 6.6 \%)$ and $S M \_B_{B H}(22.2 \pm 9.7 \%)$. Offsetting lower methane utilization was increased use of particulate sources, with $\mathrm{DSOM}_{\mathrm{BH}}$ being a major resource $(38.2 \pm 13 \%)$ and DPHY being a minor resource $(15.6 \pm 4.6 \%)$.

\section{Within-seep spatial and temporal comparisons}

There were several within-site spatial differences, as detailed in Table S1 in the Supplement. Approximately half of the comparisons showed significant differences, but most of these were based on relatively small differences. Large differences $(>5 \%$ ) were found in only about $10 \%$ of the cases, so that overall within-site spatial differences were relatively small and significant differences, when they occurred, were rare. At Bush Hill, significant bed differences were found for all 4 resources, but positional (inner vs. edge) differences were significant only for $\mathrm{SM}_{\mathrm{B}} \mathrm{B}_{\mathrm{BH}}$ and $\mathrm{DSOM}_{\mathrm{BH}}$ (see Table S1 in the Supplement). At Brine Pool, detrital $\mathrm{DSOM}_{\mathrm{BP}}$ appeared to be a uniformly available food source with no significant spatial pattern with respect to end of the pool or edge versus inner position.

Temporal differences at Bush Hill could only be examined for Bed 1 since the other beds were only sampled in a single year. Inclusion of Beds $1 \mathrm{a}$ and 2 would have confounded spatial and temporal effects (Table S3 in the Supplement). DPHY was the only 


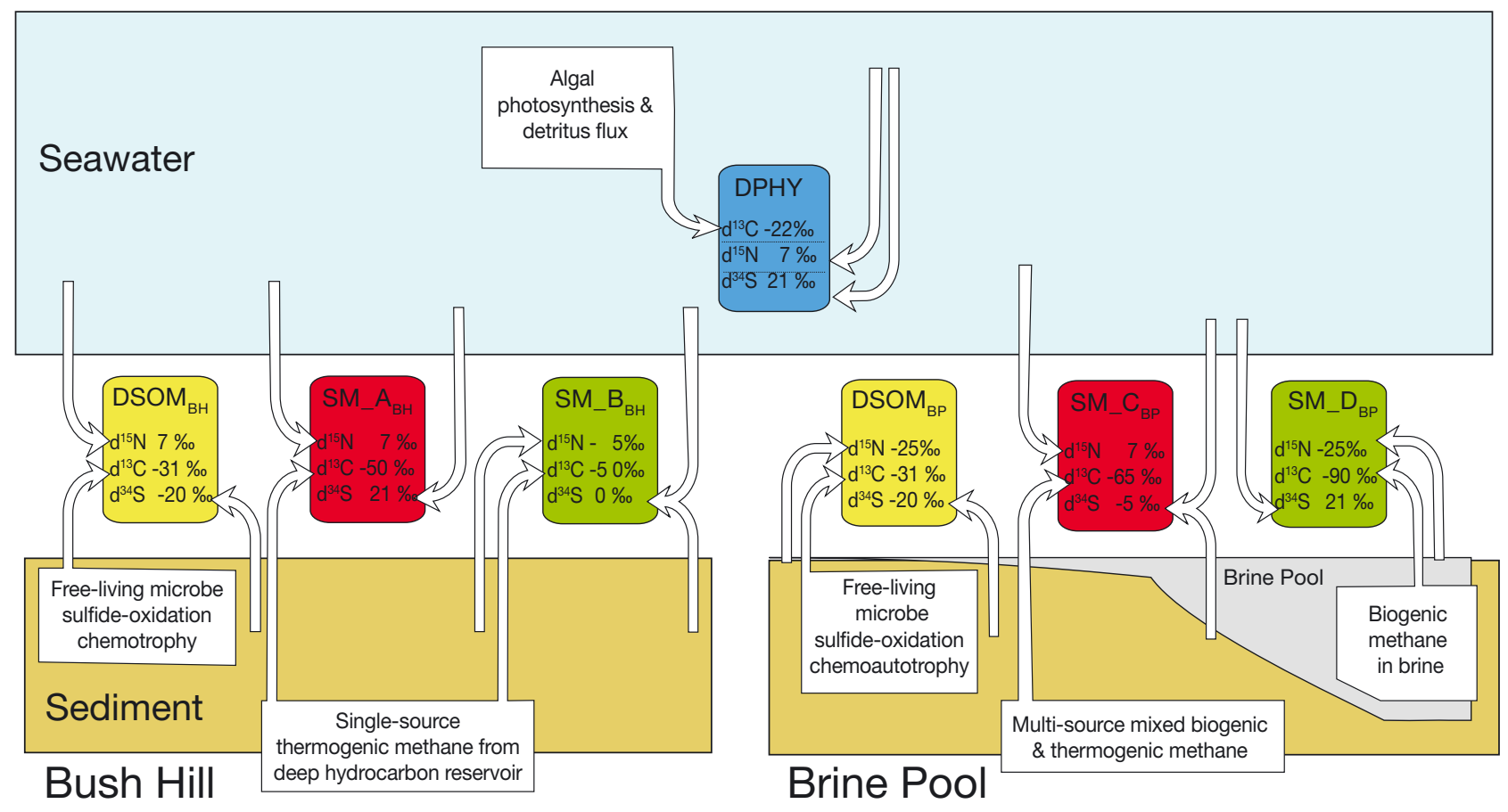

Fig. 6. Schematic representation of isotope contributions to trophic sources of Bathymodiolus childressi at Bush Hill and Brine Pool (values rounded to nearest whole number). See Table 1 for description of abbreviations

resource to be utilized homogenously between years and between positions. SM_A $\mathrm{A}_{\mathrm{BH}}$ utilization increased significantly in 1992 and was consistently lower at the edge in both years (Fig. S3 in the Supplement). SM_B $B_{B H}$ was similarly higher in 1992, and within years was consistently higher at the edge. $\mathrm{DSOM}_{\mathrm{BH}}$ was used significantly less in 1992, and there were no position effects within years.

Temporal differences at the Brine Pool were examined with an unbalanced ANOVA with 2 factors: year and pool end (Table S3). The predominant methanederived source (SM_D $D_{\mathrm{BP}}$ ) showed no significant differences of mean utilization among the 3 years (1989, 1991 and 2006) or between north and south ends (Fig. S4). In 2006, however, the north and south end mussels had significantly different means, with the south utilizing a greater proportion of SM_D $D_{\mathrm{BP}}$. Thiotrophic material was similarly homogenous among years and ends, except that in 2006 the north end utilized significantly more $\mathrm{DSOM}_{\mathrm{BP}}$. In contrast to these relatively homogenous resources, the minor methane-derived source SM_ $C_{B P}$ and DPHY utilization differed significantly across years. SM_C $\mathrm{BP}_{\mathrm{BP}}$ was lowest in 1991 and homogenous between ends. Utilization in 1989 and 2006 was not significantly different, but ends differed inconsistently. DPHY showed an inverse pattern, with the highest utilization and similar ends in 1991. Means in 1989 and 2006 were similar, and ends differed inconsistently.

Overall, the mussels at Brine Pool showed fairly uniform resource use in both spatial and temporal comparisons, with a consistent ranking of foods used: from highest to lowest, $1=$ SM_D $D_{\mathrm{BP}}, 2=\mathrm{DPHY}, 3=$ $\mathrm{DSOM}_{\mathrm{BP}}$ and $4=\mathrm{SM}_{-} \mathrm{C}_{\mathrm{BP}}$ (Figs. S1 \& S2). There was less consistency at Bush Hill, but a common pattern could be identified as $1=\mathrm{DSOM}_{\mathrm{BH}}, 2=\mathrm{SM}_{-} \mathrm{A}_{\mathrm{BH}}, 3=$ SM_B $B_{B H}$ and $4=$ DPHY (Figs. S3 \& S4). None of the Bush Hill patterns were similar to the common pattern that was almost always found at the Brine Pool (Figs. S1-S4).

\section{DISCUSSION}

\section{Modelled trophic relationships versus reality}

While the results of the mixing model are consistent with Bathymodiolus childressi having more nutritional sources than a single methanotrophic symbiont, the fact that the inferred food resources remain incompletely identified and quantified requires critical examination of model assumptions. As with all stable isotope food web mixing models, the primary cause of variation of sample values is assumed 
to be mixing of end members rather than an inherent variation around a mean value caused by other processes. This model requires that the uptake of carbon, nitrogen and sulfur be linked in foods or resources used by the mussels. Significant correlations among the 3 isotopes at both seeps indicate that this assumption was at least partially met. Earlier studies reporting no correlation among isotopes were based on fewer than 10 individuals and used only carbon and nitrogen (Lee \& Childress 1996, Duperron et al. 2007). It is further assumed that the end members identified by the analysis correspond to animals specializing on single resources. But the lack of well-characterized resources within the seep environment makes this assumption difficult to verify. The method, however, is designed to produce relatively reasonable sources, and the strategy of inferring food sources has often been used in aquatic studies where sources are difficult to quantify (e.g. Peterson et al. 1993, Wissel et al. 2005, Baker et al. 2013). In the case of this study, phytoplankton detritus is relatively well characterized and anchors one vertex of the mixing tetrahedrons (Fig. 4). The remaining 3 sources are constrained by the scatter of the actual data values, and end member placement benefits from existing geochemical information, as scant as that is. The possible nutrition sources of the mussel are limited by its well-known biology. It can depend upon symbiosis and upon particle feeding. In the deep environment, those particles can come from surface primary productivity or be created within the chemotrophic regime of the seep.

The mixing model results reported here provide an informed starting place for additional field and laboratory investigation. Field sampling of a larger number of brine-associated and brine-free seeps could be undertaken to determine if the complex pattern of brine versus sediment versus seawater is a common feature of such systems. Additionally, particulate sources could be sampled and characterized, possibly using sediment extractions followed by compound-specific methods in an effort to obtain measured field values for the potential resources identified herein. In the laboratory, labelled feeding could be used to assess the extent by which CNS are linked (as assumed by the model) or independent.

The mixing model estimates (Table 1a) have somewhat of an artificially low variance associated with them, because the inferred sources were assumed to be fixed points rather than having an associated variance. Phillips \& Gregg (2001) considered such problems and concluded that when differences between sources are relatively large (as was the case in this study; Fig. 4), propagating the error associated with source isotopes will only moderately increase final error estimates. However, these considerations led us to contemplate whether we might better adopt a significance level of $\alpha<0.01$ rather than the usual $\alpha<$ 0.05. Results showed, however, that using this more rigorous distinction did not change the significance in any of the Table $1 \mathrm{~b} t$-tests, so these appear relatively robust. Nevertheless, using $\alpha<0.01$ as a significance threshold did result in fewer within-site comparisons being significant, effects that are considered further in the Supplement.

\section{Two symbiotic-methane pathways at each seep}

The indication that Bush Hill and Brine Pool mussels apparently received methane-derived nutrition from 2 sources (Bush Hill: SM_A $\mathrm{BH}_{\mathrm{BH}}$ and SM_B $\mathrm{B}_{\mathrm{BH}}$ Brine Pool: SM_C $\mathrm{BP}_{\mathrm{BP}}$ and $\mathrm{SM}_{-} \mathrm{D}_{\mathrm{BP}}$ ) was unexpected. Three explanations can be put forward. Firstly, the mussels may contain 2 strains of methanotrophic microbes that differ in nitrogen and sulfur metabolism. The possibility of multiple strains has been previously suggested (Duperron et al. 2007). Secondly, there may be a single symbiont that experiences changing exposure to seeping fluids and seawater, thus causing a temporally lagged mixed signal in the tissue that is interpreted as 2 sources. Lastly, 1 of the 2 sources may be free-living methanotrophs consumed during filter feeding. Our data are equivocal as to which is the case.

Bush Hill appears to be the simpler system, with SM_A $A_{B H}$ containing a single source of seep methane mixed with overlying seawater, as indicated by the $\delta^{15} \mathrm{~N}$ and $\delta^{34} \mathrm{~S}$ values. Uniformity of within-bed SM_A $A_{B H}$ values indicate the ocean-mixed SM_A $A_{B H}$ is uniformly available. SM_B $B_{\mathrm{BH}}$ utilizes the same seeping methane pool but with seep sulfur and nitrogen coming from the bottom as products of ammonium and sulfate reduction. Seep-mixed SM_B $\mathrm{B}_{\mathrm{BH}}$ was spatially variable within beds, showing consistently greater utilization at the bed edges.

At Brine Pool, the sources of carbon, nitrogen and sulfur are more complex due to the multiple interfaces and gradients experienced by the mussels: seawater-sediment, seawater-brine and brinesediment. SM_C $C_{B P}$ may be sediment-associated with a more enriched mixture of thermogenic and biogenic methane. The sulfur originates as sulfide seeping out of the reduced sediments under the mussel mat, and seawater nitrate provides the nitrogen. The other methane-pathway resource 
$\left(\mathrm{SM}_{-} \mathrm{D}_{\mathrm{BP}}\right)$ is more strongly influenced by the brine reservoir. That provides heavily depleted biogenic methane and depleted ammonium, both originating somewhere within the subsurface brine-sediment system. The primary source of sulfur in this resource must be from seawater sulfate since the brine itself lacks sulfur.

\section{Site differences in particulate food}

The question can be posed as to whether the thiotrophic sources $\mathrm{DSOM}_{\mathrm{BH}}$ and $\mathrm{DSOM}_{\mathrm{BP}}$ might also represent a symbiont rather than free-living microbes. Previous findings, however, suggest that this is highly unlikely. The symbiotes of $B$. childressi have consistently been identified as methanotrophs by morphological and molecular criteria applied at multiple collection sites (Childress et al. 1986, Brooks et al. 1987, Fisher 1990, Distel \& Cavanaugh 1994, Duperron et al. 2007). The high level of consumption of particulate thiotrophic resources rather than photosynthetic detritus was an unexpected finding. A parsimonious explanation is that in the seep habitats, DPHY, $\mathrm{DSOM}_{\mathrm{BH}}$ and $\mathrm{DSOM}_{\mathrm{BP}}$ contribute to the particulate detritus that has been observed as both as a thick layer under the mussels and a thin dusting on the surface of shells (Zande \& Carney 2001). It is a mixture that includes photosynthetic algae from the euphotic zone along with surficial and interstitial sediment produced in situ by microbial chemoautotrophs (Orcutt et al. 2005). It is this same detrital mix that supports the fully heterotrophic detritivores found at seeps and vents (Carney 1994, Van Dover \& Fry 1994, MacAvoy et al. 2002, Becker et al. 2013). The greater utilization of $\mathrm{DSOM}_{\mathrm{BH}}$ at Bush Hill is consistent with previous determinations that Bush Hill is a more sulfide-rich habitat than Brine Pool. It has been suggested that the dense tubeworm populations at Bush Hill, in conjunction with microbial mats, promote sulfide generation in excess of rates limited by sulfate diffusion from seawater (Arvidson et al. 2004, Joye et al. 2010, Bowles et al. 2011).

Interpretation of correlations among proportions must be done cautiously since large negative values are to be expected (Chayes 1960); however, correlations among apparent resource utilizations provide a clue as to whether availability of some combinations of those resources are linked. If the detrital pool at seeps has a locally uniform composition and is nonselectively consumed, then the uptake of DPHY and DSOM would be expected to be positively correlated and negatively correlated with one or both methane pathways. Such a simple mixed detritus pool was found only in the Brine Pool samples from 2006 (Table S3). In the earlier Brine Pool samples, DPHY and $\mathrm{DSOM}_{\mathrm{BP}}$ utilization were essentially independent $(\mathrm{r}=0.17)$, indicating small-scale heterogeneity in the composition of the detrital resources. At Bush Hill, with its high utilization of $\mathrm{DSOM}_{\mathrm{BH}}$, DPHY and $\mathrm{DSOM}_{\mathrm{BH}}$ utilization appear to be antagonistic $(\mathrm{r}=$ $-0.57)$. Selective feeding or assimilation could help explain some of these weaker correlations.

An alternate to the detritus explanation for $\mathrm{DSOM}_{\mathrm{BH}}$ and $\mathrm{DSOM}_{\mathrm{BP}}$ is that they represent symbiotic rather than free living thiotrophic microbes. This possibility of an overlooked dual symbiosis cannot be eliminated on the basis of the analyses conducted here, but is inconsistent with what is known about chemosynthesis in the this species. B. childressi has repeatedly been found to be dependent on only methanotrophic symbionts based on stable isotopes, metabolic function and DNA (Fisher 1990, Duperron et al. 2013). While none of those assays have been carried out with highly replicated sampling, it is unlikely that a major thiotrophic symbiosis could have escaped detection.

\section{Within-seep spatial source variation}

The original sampling design took into consideration that $B$. childressi beds are spatially well defined, with distinct boundaries assumed to coincide with the outer boundary of the methane-seeping patch of bottom. Comparison of mussels from a bed's outer edge with those from the inner area was expected to reveal gradients in resource availability and utilization, with methane resources being greatest at the interior. For those trophic resources which had significant and consistent within-bed differences (see Table S2), the position of higher utilization was often counter to expectation. At Bush Hill, all isotope values of SM_B $B_{B H}$ indicated seep sources were utilized most heavily at the outer edges rather than inner areas of the bed.

Examination of spatial patterns of utilization extremes revealed small-scale patchiness. At Bush Hill, 94 specimens showed $>50 \%$ dependence on particles. Of these highest particle users, 5 were collected in a single 1991 scoop at the edge of Bed 1. Either particle availability was quite high there or methane pathway resources were locally reduced. At the Brine Pool, 6 mussels had particulate resource utilizations below $20 \%$. These low-particulate mussels were clumped, with 4 collected in a single 1989 scoop at the northern edge and 2 from a single sample at the south end in 2006. It can be postulated that these 
samples came from small patches with either a limited supply of particulate material or a locally high source of methane pathway resources.

\section{Temporal variation}

The finding of temporal variation in trophic source utilization at Bush Hill is consistent with large variation in fluid flux rates during a $430 \mathrm{~d}$ monitoring that occurred at that seep between June 2002 and July 2003 (Solomon et al. 2008). Fluid flux measured at a mussel bed similar to our Beds 1 and 1a varied from an outflow of $32 \mathrm{~cm} \mathrm{yr}^{-1}$ to an inflow of $-63 \mathrm{~cm} \mathrm{yr}^{-1}$. If similar conditions were present in 1991 and 1992, the beds may have experienced extended periods with no methane available to support the mussel symbiotes. Similar temporal monitoring has not been carried out at the Brine Pool. This finding may indicate that trophic source utilization in 2006 at Brine Pool was comparatively similar to 1989 and that the pool represents a large methane reservoir with only modest changes occurring over a span of decades.

There is a possibility for both seeps that the apparent resource utilization of each mussel is an integration of temporal changes rather than a persistent current state. Dattagupta et al. (2004) transplanted B. childressi between Brine Pool, Bush Hill and Green Canyon 234 (a site with Bush Hill-like mussel populations) and determined isotopic changes associated with growth and metabolic turnover after a period of $1 \mathrm{yr}$. Isotopic values shifted from the population of origin to that of the receiving population but were incomplete after the 1 yr study. Mussels moved from the Brine Pool to Bush Hill had a combined metabolic and growth turnover of $40.5 \% \delta^{13} \mathrm{C} \mathrm{yr}^{-1}$, $17.9 \% \delta^{15} \mathrm{~N} \mathrm{yr}^{-1}$ and $76.3 \% \delta^{34} \mathrm{~S} \mathrm{yr}^{-1}$. Turnover of $\delta^{13} \mathrm{C}$ and $\delta^{15} \mathrm{~N}$ were correlated but not $\delta^{34} \mathrm{~S}$. At such relatively low turnover rates, mussel tissue should reflect trophic conditions that occurred over the previous several months to a year.

\section{Future directions}

Since the samples that we analyzed herein were collected, there has been a substantial increase in our understanding of the biology of B. childressi, based in large part on studies conducted at the Brine Pool. There, the population produces gametes in synchrony with a long October to February spawning season (Tyler et al. 2007) followed by a relatively long period of dispersion in the plankton (Arellano \&
Young 2009, Arellano et al. 2014). The possibility that assimilation of detrital sources occurs during gametogenesis and spring plankton blooms should be assessed by means of annual temporal sampling. Since bathyomodiolin mussels acquire symbiont microbes from the environment after settling, a transition in food sources must occur with growth as modelled by Martins et al. (2008) for B. azoricus. Unfortunately, the sample archives we used lacked a sufficient number of all size classes to carry out a robust analysis of size-specific diets. Analyses over the available size range did indicate a size effect, but it was inconsistent between sites. At Brine Pool the correlation between shell length and DPHY was 0.59, indicating an important diet increase with increasing size. At Bush Hill, however, a similarly high correlation of 0.44 occurred between length and the SM_A $A_{B H}$ source. An explanation for such a difference in size effects on diet cannot be resolved from the archival samples.

\section{CONCLUSIONS}

Bathymodiolus childressi is a highly resilient organism that can utilize the multiple food sources afforded by hydrocarbon seep systems. The use of thiotrophic and phytoplankton-based detritus establishes that the Brine Pool and Bush Hill populations of $B$. childressi are mixotrophic and supplement their methane-derived symbiotic food by feeding on both photic zone-derived and seep-derived detrital products. Non-methane sources are more important at Bush Hill, where methane flux has been demonstrated to be highly variable and mussel condition poor relative to Brine Pool. Those particulate resources contribute to nutrition but are less important at Brine Pool, where sub-seafloor brine conduits may provide a more stable source of methane. Small-scale patches of mussels exist at both seeps, where source utilization is quite different than the seep averages. Mechanisms producing such small patches could not be identified in the current study.

Future research should be directed at 2 related objectives. Firstly, the presence, nature and incorporation routes of multiple sources should be confirmed with new and more targeted sampling and live-culture experiments. Secondly, the within-seep trophic variation should be assessed by means of similar studies of many more systems. The results reported here are based on a high level of replication of mussel specimens but a low level of replication of seeps, positions within seeps and times of sampling. There 
was no replication of the 2 types of seeps, i.e. those with and without brine. Such replication should be incorporated into future designs.

Acknowledgements. The original sampling was greatly facilitated by the ships' crews and Johnson Sea Link submersible teams of the Harbor Branch Oceanographic Institute. Funding for that sampling was provided by the Bureau of Ocean Energy Management (BOEM) of the US Department of the Interior and the Ocean Exploration and Research Program of the National Ocean and Atmospheric Administration of the Department of Commerce. Support for this archive analysis was provided to R.S.C. and B.F. by BOEM contract M10AC2008. Discussions with Shawn Arellano and Dr. Craig Young helped in our understanding of the seep mussel system. J. J. Hipes assisted in sample preparation. Dr. Jill Olin and 3 anonymous reviewers contributed to the improvement of the manuscript.

\section{LITERATURE CITED}

Aharon P, Fu B (2000) Microbial sulfate reduction rates and sulfur and oxygen isotope fractionation at oil and gas seeps in deepwater Gulf of Mexico. Geochim Cosmochim Acta 64:233-246

> Arellano SM, Young CM (2009) Spawning, development and the duration of larval life in a deep-sea cold-seep mussel. Biol Bull (Woods Hole) 216:149-162

Arellano SM, Van Gaest AL, Johnson SB, Vrijenhoek RC, Young CM (2014) Larvae from deep-sea methane seeps disperse in surface waters. Proc R Soc Lond B 281: 20133276

Arvidson RS, Morse JW, Joye SB (2004) The sulfur biogeochemistry of chemosynthetic cold seep communities, Gulf of Mexico, USA. Mar Chem 87:97-119

> Baker R, Fry B, Rozas LP, Minello TJ (2013) Hydrodynamic regulation of salt marsh contributions to aquatic food webs. Mar Ecol Prog Ser 490:37-52

> Barnes C, Jennings S, Polumin NVC, Lancaster JE (2008) The importance of quantifying inherent variability when interpreting stable isotope field data. Oecologia 155: 227-235

Becker EL, Lee RW, Macko SA, Faure BM, Fisher CR (2010) Stable carbon and nitrogen isotope compositions of hydrocarbon-seep bivalves on the Gulf of Mexico lower continental slope. Deep-Sea Res II 57:1956-1964

Becker EL, Cordes E, Macko SA, Lee RW, Fisher CR (2013) Using stable isotope compositions of animal tissues to infer trophic interactions in Gulf of Mexico lower slope seep communities. PLoS ONE 8:e74459

Bernard BB, Brooks JM, Sackett WM (1978) Light hydrocarbons in recent Texas continental shelf and slope sediments. J Geophys Res 83:4053-4061

> Bergquist DC, Fleckenstein C, Szalai EB, Knisel J, Fisher CR (2004) Environment drives physiological variability in the cold seep mussel Bathymodiolus childressi. Limnol Oceanogr 49:706-715

> Biggs DC, Hu C, Müller-Karger FE (2008) Remotely sensed sea-surface chlorophyll and POC flux at deep Gulf of Mexico benthos sampling stations. Deep-Sea Res II 55: 2555-2562

Bowles MW, Samarkin VA, Bowles KM, Joye SB (2011) Weak coupling between sulfate reduction and the anaer- obic oxidation of methane in methane-rich seafloor sediments during ex situ incubation. Geochim Cosmochim Acta 75:500-519

Bowman AW, Azzalini A (2013) R package 'sm': nonparametric smoothing methods (version 2.2-5).http://cran.rproject.org/web/packages/sm/sm.pdf

Brooks JM, Kennicutt MC, Fisher CR, Macko SA and others (1987) Deep-sea hydrocarbon seep communities: evidence for energy and nutritional carbon sources. Science 238:1138-1142

Canfield DE (2001) Isotope fractionation by natural populations of sulfate-reducing bacteria. Geochim Cosmochim Acta 65:1117-1124

Carney RS (1994) Consideration of the oasis analogy for chemosynthetic communities at Gulf of Mexico hydrocarbon vents. Geo-Mar Lett 14:149-159

$>$ Chayes F (1960) On correlations between variables of constant sum. J Geophys Res 65:4185-4193

> Chen DF, Cathles LM III (2003) A kinetic model for the pattern and amounts of hydrate precipitated from a gas stream: application to the Bush Hill vent site, Green Canyon Block 185, Gulf of Mexico. J Geophys Res 108: 2058

Childress JJ, Fisher CR, Brooks JM, Kennicutt MC, Bidigare $\mathrm{R}$, Anderson AE (1986) A methanotrophic marine molluscan (Bivalvia, Mytilidae) symbiosis: mussels fueled by gas. Science 233:1306-1308

> Colaço A, Prieto C, Martins A, Figueiredo M, Lafon V, Monteiro M, Bandarra NM (2009) Seasonal variations in lipid composition of the hydrothermal vent mussel Bathymodiolus azoricus from the Menez Gwen vent field. Mar Environ Res 67:146-152

$>$ Cordes EE, Bergquist DC, Katriona S, Fisher CR (2003) Hydrogen sulphide demand of long-lived vestimentiferan tube worm aggregations modifies the chemical environment at deep-sea hydrocarbon seeps. Ecol Lett 6 : 212-219

Cordes EE, Bergquist DC, Fisher CR (2009) Macro-ecology of Gulf of Mexico cold seeps. Annu Rev Mar Sci 1:143-168

> Dale AW, Bruchert V, Alperin M, Regnier P (2009) An integrated sulfur model for Namibian shelf sediments. Geochim Cosmochim Acta 73:1924-1944

> Dattagupta S, Bergquist DC, Szalai EB (2004) Tissue carbon, nitrogen and sulfur isotope turnover in transplanted Bathymodiolus childressi mussels: relation to growth and physiological condition. Limnol Oceanogr 49:1144-1151

> De Busserolles F, Sarrazin J, Gauthier O, Gélinas Y, Fabri MC, Sarradin PM, Desbruyères D (2009) Are spatial variations in the diets of hydrothermal fauna linked to local environmental conditions? Deep-Sea Res II 56: 1649-1664

> Demopoulos AWJ, Gualtieri D, Kovacs K (2010) Food-web structure of seep sediment macrobenthos from the Gulf of Mexico. Deep-Sea Res II 57:1972-1981

> Distel DL, Cavanaugh CM (1994) Independent phylogenetic origins of methanotrophic and chemotrophic bacterial endosymbioses in marine bivalves. J Bacteriol 176: 1932-1938

Distel DL, Lee HKW, Cavanaugh CM (1995) Intercellular coexistence of methano- and thioautotrophic bacteria in a hydrothermal vent mussel. Proc Natl Acad Sci USA 92: 9598-9602

> Duperron S, Sibuet M, MacGregor BJ, Kuypers MMM, Fisher CR, Dubilier N (2007) Diversity, relative abundance and metabolic potential of bacterial endosymbionts 
in three Bathymodiolus mussel species from cold seeps in the Gulf of Mexico. Environ Microbiol 9:1423-1438

- Duperron S, Gaudron SM, Rodrigues CF, Chuna MR, Decker C, Olu K (2013) An overview of chemosynthetic symbioses in bivalves from the North Atlantic and Mediterranean Sea. Biogeosciences 10:3241-3267

Faure B, Schaeffer SW, Fisher CR (2015) Species distribution and population connectivity of deep-sea mussels at hydrocarbon seeps in the Gulf of Mexico. PLoS ONE 10: $\mathrm{e} 0118460$

Fisher CR (1990) Chemoautoptrophic and methanotrophic symbioses in marine invertebrates. Rev Aquat Sci 2: $399-436$

Fontanez KM, Cavanaugh CM (2013) Phylogenetic relationships of hydrothermal vent mussels (Bathymodiolinae) and their symbionts. Mar Ecol Prog Ser 474:147-154

Fry B (2007) Coupled N, C and S stable isotope measurements using a dual-column gas chromatography system. Rapid Commun Mass Spectrom 21:750-756

> Fry B (2013) Alternative approaches for solving underdetermined isotope mixing problems. Mar Ecol Prog Ser 472: $1-13$

Fu B (1998) A study of pore fluids and barite deposits from hydrocarbon seeps: deepwater Gulf of Mexico. PhD dissertation. Louisiana State University, Baton Rouge, LA

Gustafson RG, Turner RD, Lutz RA, Vrijenhoek RC (1998) A new genus and five new species of mussels (Bivalvia, Mytilidae) from deep-sea sulfide/hydrocarbon seeps in the Gulf of Mexico. Malacologia 40:63-112

Hoch MP, Fogel ML, Kirchman DL (1992) Isotope fractionation associated with ammonium uptake by a marine bacterium. Limnol Oceanogr 37:1447-1459

Joye SB, MacDonald IR, Montoya JP, Peccini M (2005) Geophysical and geochemical signatures of Gulf of Mexico seafloor brines. Biogeosciences 2:295-309

> Joye SB, Bowles MW, Samarkin VA, Hunter KS, Niemann H (2010) Biogeochemical signatures and microbial activity of different cold-seep habitats along the Gulf of Mexico deep slope. Deep-Sea Res II 57:1990-2001

Le Pennec M (1988) Alimentation et reproduction d'un mytalidae des sources hydrothermales profondes du Pacifique oriental. Oceanol Acta 8:181-190

Le Pennec M, Prieur D (1984) Anatomie, structure et ultrastructure de la branchie d'un mytilidae des sites hydrothermaux Pacific oriental. Oceanol Acta 7:517-523

> Lee RW, Childress JJ (1994) Assimilation of inorganic nitrogen by marine invertebrates and their chemotrophic and methanotrophic symbionts. Appl Environ Microbiol 60: 1852-1858

- Lee RW, Childress JJ (1996) Inorganic N assimilation and ammonium pools in a deep-sea mussel containing methanotrophic endosymbionts. Biol Bull (Woods Hole) 190:373-384

Lee RW, Robinson JJ, Cavanaugh CM (1999) Pathways of inorganic nitrogen assimilation in chemotrophic bacteria-marine invertebrate symbioses: expression of host and symbiont glutamine synthetase. J Exp Biol 202: 289-300

Liu KK, Kaplan IR (1989) The eastern tropical Pacific as a source of ${ }^{15} \mathrm{~N}$-enriched nitrate in seawater off southern California. Limnol Oceanogr 34:820-830

MacAvoy SE, Carney RS, Fisher CR, Macko SA (2002) Use of chemosynthetic biomass by large, mobile, benthic predators in the Gulf of Mexico. Mar Ecol Prog Ser 225: 65-78
MacAvoy SE, Fisher CR, Carney RS, Macko SA (2005) Nutritional associations among fauna at hydrocarbon seep communities in the Gulf of Mexico. Mar Ecol Prog Ser 292:51-60

> MacAvoy SE, Morgan E, Carney RS, Macko SA (2008) Chemotrophic production incorporated by heterotrophs in Gulf of Mexico hydrocarbon seeps: an examination of mobile benthic predators and seep residents. J Shellfish Res 27:153-161

> MacDonald IR, Peccini MB (2009) Distinct activity phases during the recent geologic history of a Gulf of Mexico mud volcano. Mar Pet Geol 26:1824-1830

> MacDonald IR, Reilly JF II, Guinasso NL, Brooks JM, Carney RS, Bryant WA, Bright TJ (1990) Chemosynthetic mussels in a brine-filled pockmark in the northern Gulf of Mexico. Science 248:1096-1099

> MacDonald IR, Sager WW, Peccini MB (2003) Gas hydrate and chemosynthetic biota in mounded bathymetry at mid-slope hydrocarbon seeps: northern Gulf of Mexico. Mar Geol 198:133-158

Martins I, Colaco A, Dando P, Martins I, Desbruyeres D, Sarradin PM, Marques J and others (2008) Size-dependent variations on the nutritional pathway of Bathymodiolus azoricus demonstrated by a C-flux model. Ecol Model 217:59-71

Miyazaki JI, de Oliveira Martins L, Fujita Y, Matsumoto H, Fujiwara Y (2010) Evolutionary process of deep-sea Bathymodiolus mussels. PLoS ONE 5:e10363

Nix ER, Fisher CR, Vodenichar J, Scott KM (1995) Physiological ecology of a mussel with methanotrophic endosymbionts at three hydrocarbon seep sites in the Gulf of Mexico. Mar Biol 122:605-617

> Olu-Le Roy K, von Cosel R, Hourdez S, Carney SL, Jollivet D (2007) Amphi-Atlantic cold-seep Bathymodiolus species complexes across the equatorial belt. Deep-Sea Res I 54: 1890-1911

> Orcutt BN, Boetius A, Elvert M, Samarkin VA, Joye S (2005) Molecular biogeochemistry of sulfate reduction, methanogenesis and the anaerobic oxidation of methane at Gulf of Mexico cold seeps. Geochim Cosmochim Acta 69: 4267-4281

> Page HM, Fisher CR, Childress JJ (1990) Role of filter-feeding in the nutritional biology of a deep-sea mussel with methanotrophic symbionts. Mar Biol 104:251-257

> Peterson B, Fry B (1987) Stable isotopes in ecosystem studies. Annu Rev Ecol Syst 18:293-320

Peterson B, Fry B, Deegan L, Hershey A (1993) The trophic significance of epilithic algal production in a fertilized tundra river ecosystem. Limnol Oceanogr 38:872-878

Phillips DL (2012) Converting isotope values to diet composition: the use of mixing models. J Mammal 93:342-352

Phillips DL, Gregg JW (2001) Uncertainty in source partitioning using stable isotopes. Oecologia 127:171-179

Pile AJ, Young CM (1999) Plankton availability and retention efficiencies of cold-seep symbiotic mussels. Limnol Oceanogr 44:1833-1839

Rees CE, Jenkins WJ, Monster J (1978) The sulphur isotopic composition of ocean water sulphate. Geochim Cosmochim Acta 42:377-381

Riou V, Colaço A, Bouillon S, Khripounoff A and others (2010a) Mixotrophy in the deep sea: a dual endosymbiotic hydrothermal mytilid assimilates dissolved and particulate organic matter. Mar Ecol Prog Ser 405:187-201

Riou V, Duperron S, Harlary S, Dehairs F and others (2010b) Variation in physiological indicators in Bathymodiolus 
azoricus (Bivalvia:Mytilidae) at the Menez Gwen MidAtlantic Ridge deep-sea hydrothermal vent site within a year. Mar Environ Res 70:264-271

Rodrigues CF, Hilario A, Cunha MR (2013) Chemosymbiotic species from the Gulf of Cadiz (NE Atlantic): distribution, life styles and nutritional patterns. Biogeosciences 10: 2569-2581

Rooker JR, Turner JP, Holt SA (2006) Trophic ecology of Sargassum-associated fishes in the Gulf of Mexico determined from stable isotopes and fatty acids. Mar Ecol Prog Ser 313:249-259

Sassen R, Joye S, Sweet ST, DeFreitas DA, Milkov AV, MacDonald IR (1999) Thermogenic gas hydrates and hydrocarbon gases in complex chemosynthetic communities, Gulf of Mexico continental slope. Org Geochem 30:485-497

Sassen R, Roberts HH, Carney RS, Milkov AV, DeFreitas DA, Lanoil B, Zhang C (2004) Free hydrocarbon gas, gas hydrate, and authigenic minerals in chemosynthetic communities of the northern Gulf of Mexico continental slope: relation to microbial processes. Chem Geol 205:195-217

Smith EB, Scott KM, Nix ER, Korte C, Fisher CR (2000) Growth and condition of seep mussels (Bathymodiolus childressi) at a Gulf of Mexico brine pool. Ecology 81: 2392-2403

Solomon EA, Kastner M, Jannasch H, Robertson G, Weinstein Y (2008) Dynamic fluid flow and chemical fluxes associated with a seafloor gas hydrate deposit on the northern Gulf of Mexico Slope. Earth Planet Sci Lett 270: 95-105

Streams ME, Fisher CR, Fiala-Medioni A (1997) Methanotrophic symbiont location and fate of carbon incorporated from methane in a hydrocarbon seep mussel. Mar Biol 129:465-476

Templeton AS, Chu KH, Alvarez-Cohen L, Conrad ME (2006) Variable carbon isotope fractionation expressed by aerobic $\mathrm{CH}_{4}$-oxidizing bacteria. Geochim Cosmochim Acta 70:1739-1752

Editorial responsibility: Charles Peterson, Morehead City, North Carolina, USA
Trask JL, Van Dover CL (1999) Site-specific and ontogenetic variations in nutrition of mussels (Bathymodiolus sp.) from the Lucky Strike hydrothermal vent field, MidAtlantic Ridge. Limnol Oceanogr 44:334-343

> Tryon MD, Brown KM (2004) Fluid and chemical cycling at Bush Hill: implications for gas- and hydrate-rich environments. Geochem Geophys Geosyst 5:Q12004, doi: 10.1029/2004GC000778

Tyler P, Young CM, Dolan E, Arellano SM, Brooke S, Baker $M$ (2007) Gametogenic periodicity in the chemosynthetic cold-seep mussel 'Bathymodiolus' childressi. Mar Biol 150:829-840

- Van Dover CL, Fry B (1994) Microorganisms as food resources at deep-sea hydrothermal vents. Limnol Oceanogr 39:51-57

Wankel SD, Joye SB, Samarkin VA, Shah SR, Friederich G, Melas-Kyriazi J, Girguis PR (2010) New constraints on methane fluxes and rates of anaerobic methane oxidation in a Gulf of Mexico brine pool via in situ mass spectrometry. Deep-Sea Res II 57:2022-2029

Wells RJD, Rooker JR (2009) Feeding ecology of pelagic fish larvae and juveniles in slope waters of the Gulf of Mexico. J Fish Biol 75:1719-1732

Whiticar MJ (1999) Carbon and hydrogen isotope systematics of bacterial formation and oxidation of methane. Chem Geol 161:291-314

- Wissel B, Gaçe A, Fry B (2005) Tracing river influences on phytoplankton dynamics in two Louisiana estuaries. Ecology 86:2751-2762

> Wortmann UG, Bernasconi SM, Böttcher ME (2001) Hypersulfidic deep biosphere indicates extreme sulfur isotope fractionation during single-step microbial sulfate reduction. Geology 29:647-650

Zande JM, Carney RS (2001) Population size structure and feeding biology of Bathynerita naticoidea Clarke 1989 (Gastropoda: Neritacea) from Gulf of Mexico hydrocarbon seeps. Gulf Mex Sci 19:107-118

Submitted: December 15, 2014; Accepted: February 11, 2016 Proofs received from author(s): March 20, 2016 